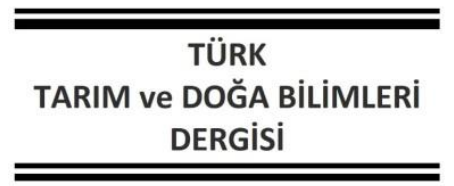

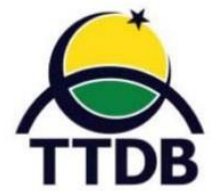

www.dergipark.gov.tr/turkjans

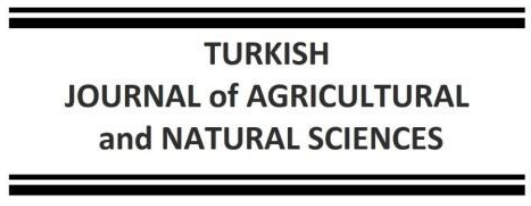

\title{
Araştırma Makalesi \\ Hanelerin Balık Tüketim Sıklığına Etki Eden Faktörlerin Sıralı Probit Model ile Analizi ${ }^{\text {\& }}$
}

\author{
Seda TERIN, Atilla KESKIN ${ }^{1 *}$ \\ ${ }^{1}$ Atatürk Üniversitesi, Ziraat Fakültesi, Tarım Ekonomisi Bölümü, Erzurum \\ *Sorumlu Yazar: akeskin.25@gmail.com
}

Geliş Tarihi: 03.05.2021 Düzeltme Geliş Tarihi: 31.05.2021 Kabul Tarihi: 30.06.2021

\section{Öz}

Araştırmada, Van ili İpekyolu ilçesinde hanelerin balık tüketim sıklığına etki eden sosyo-ekonomik ve demografik faktörler belirlenmeye çalışılmıştır. Araştırmanın ana materyalini, Van ili İpekyolu ilçesinde ikamet eden ve oransal örnekleme yöntemi kullanılarak tespit edilen 182 haneden toplanan anket verileri oluşturmaktadır. Araştırmada hanelerin balık tüketim sıklığına etki eden faktörler sıralı probit model ile analiz edilmiştir. Araştırmada hanelerin \%92,9'unun balık tükettiği ve \%7,1'inin balık tüketmediği belirlenmiştir. Araştırmada, yaş ve hane reisinin bayan olmasının hanelerin balık tüketim sıklı̆ını azalttığı, hanede tüketilen balığı yeterli olduğunu düşünme, hane reisinin evli olması, aylık ortalama balık tüketim harcaması, balığı balıkçıdan satın alma, aylık ortalama hane gelirinin asgari ücretin altında olması, kişi başına düşen balık tüketim miktarı ve hane halkı büyüklüğü değişkenlerinin hanelerin balık tüketim sıklığını arttırdığı belirlenmiştir. Araştırmada, hanelerin büyük bir çoğunluğunun balık tükettiği, kişi başına düşen balık tüketim miktarının Türkiye ortalamasından yüksek ancak dünya ortalamasından düşük olduğu belirlenmiştir. Sonuç olarak hanelerin daha sık balık tüketmesi için annelere yönelik yapılacak eğitim çalışmalarına, taze balığa ulaşım imkânları ve balık restoranlarının sayısının arttırılması konularında yapılacak çalışmalara ihtiyaç olduğu değerlendirilmektedir.

Anahtar kelimeler: Balık tüketimi, hane halkı, sıralı probit model, İpekyolu, Van

\section{Analysis of Factors Affecting Household Fish Consumption Frequency with the Ordered Probit Model}

\begin{abstract}
In this study, demographic and economic factors affecting fish consumption frequencies are determined in Ipekyolu district of Van province. Main material of the study consists of 182 respondents, residing in ipekyolu district of Van province, calculated through proportional sampling method. In the study, the factors affecting the fish consumption frequency of the households were analyzed with the ordered probit model. According to the results, it is found that \%92.9 of households consume fish while \%7.1 of them do not consume fish. Head of households age and households with a female headed have negative effect on fish consumption frequencies and consideration of sufficient fish consumed in the family, households with a married head, monthly average expenditure on fish, purchasing fish from fisher, having less income than official minimum wage, average fish consumption per capita and size of households have positive effect on fish consumption frequencies. In the study, most households in the district consume fish and average consumption per person is higher than Turkey's average however, less than world average. As a conclusion, trainings for mothers, access to fresh fish opportunities and increasing the number of fish restaurants will make significant contributions for households to consume fish more frequently.
\end{abstract}

Key words: Fish consumption, households, ordered probit model, İpekyolu, Van 


\section{Giriş}

Hayvansal kaynaklı gıda maddeleri arasında et ve et ürünleri önemli bir yere sahiptir. Et ve et ürünleri, yüksek protein içeriği nedeniyle yeterli ve dengeli beslenme açısından oldukça önemlidir. Özellikle son yıllarda yeterli ve sağlıklı beslenme önemli oranda teşvik edilmekte ve bu durum farklı gıda tüketim eğilimlerinin ortaya çıkmasına neden olmaktadır (Gilbert, 2000; Leek ve ark., 2000). Bu eğilimler arasında en dikkat çeken durum tüketicilerin kırmızı et tercihlerini azalttığı ve diyetetik özellikteki düşük enerjisi nedeniyle tavuk ve balıketini tercih etmeye başladığı ve bu değişimde göreli olarak fiyat düşüklüğünün ve tüketicilerin sosyo ekonomik yapılarındaki değişimin önemli etkisi olduğu ifade edilmektedir (Rickertsen, 1996; Mangen ve Burrell, 2001).

Balık etinin sindiriminin kolay olması, yüksek protein ve yağ içermesi (Omega 3) bunun yanı sıra taşıdığı vitamin ve mineral maddeler ile diyetetik özellikteki düşük enerjisi yeterli ve sağlıklı beslenmede balık tüketimini önemli hale getirmektedir (Tatar, 1995; Turan ve ark., 2006; Saygı ve ark., 2015; Terin ve ark., 2016; Karakaya ve ark., 2018). Yeterli ve düzenli balık tüketiminin, kalp hastalıkları ve birçok kronik hastalığa yakalanma olasılığını azalttığı Kornitzer (2001) ve daha sağlıklı bir yaşama önemli katkılar sağladığı ifade edilmiştir (Verbeke ve Vackier, 2005). Bu nedenle uzmanlar, sağlıklı bir yaşam için haftada en az iki kez balık tüketilmesini önermektedir.

Dünyada kişi başına düşen su ürünleri tüketimi üretimdeki artışa paralel olarak artmaktadır. Dünyada kişi başına düşen su ürünleri tüketimi 1961 yılında 9 kg iken 1.26 kat artarak 2016 yılı itibariyle 20.3 kg'a yükselmiştir (FAO, 2018). Ancak Türkiye'de kişi başına düşen su ürünleri tüketimi üretimdeki dalgalanmalar ve nüfus artışı nedeniyle dünya ortalamasının oldukça altındadır. Türkiye'de kişi başına yıllık ortalama su ürünleri tüketimi 2000 yılında $8 \mathrm{~kg}$ iken, \%23.8 oranında azalarak 2019 yılında $6.3 \quad$ kg'ma gerilemiştir (Anonim, 2020).

Dünyada yapılan birçok çalışmada yaşanılan bölgenin deniz kıyısında olmasının, su ürünleri tüketimini arttırdığı Myrland ve ark (2000), Trondsen ve ark (2004), Verbeke ve Vackier (2005) belirlenmiştir. Benzer durum Türkiye içinde geçerlidir. Türkiye'de denize kıyısı olan bölgelerde tüketim yüksek iken, İç, Doğu ve Güneydoğu bölgelerinde tüketim daha düşüktür. Örneğin İzmir ili ve kıyalarında $26.3 \mathrm{~kg} / \mathrm{yıl}$ Elbek ve ark (1997), Giresun ve Trabzon illerinde 28.08 kg/yıl Aydın ve Karadurmuş (2013), Mersin ilinde 25.8 kg/yıl Şen (2011) ve Tekirdağ ilinde 14.69 kg/yıl Abdikoğlu ve ark (2020) iken Isparta ilinde $12.4 \mathrm{~kg} / \mathrm{yıl} \mathrm{Hatırlı} \mathrm{ve}$ ark (2004), Erzurum ilinde $6.5 \mathrm{~kg} / \mathrm{yll}$ Uzundumlu ve ark (2013), Kahramanmaraş ilinde $6 \mathrm{~kg} / \mathrm{yll}$ Beyazbayrak (2014) Ankara ilinde 3.4 kg/yıl Gül Yavuz ve ark (2015), Siirt ilinde 4.5 kg/yıl Karakaya ve ark (2018) ve Bingöl ilinde 12.2 kg/yıl Karakaya ve Kırıcı (2016) olduğu belirlenmiştir.

Van İli, Türkiye'nin en doğusunda yer almasına ve denizlere uzak olmasına rağmen, Van Gölü sayesinde 2018 yılı itibariyle avlanan tatlı su ürünleri miktarının \%32.9'unu (9945 ton) tek başına karşılamaktadır (TÜik, 2019). Bunun yanı sıra Van ilinde 38 adet alabalık üretim çiftliği bulunmakta olup, önemli bir alabalık üretim potansiyele sahiptir (Anonim, 2018a). Tüm bu veriler dikkate alındığında denizlere kıyısı olmamasına rağmen Van ilinde su ürünleri üretim potansiyelinin iyi olduğu söylenebilir.

Van ilinde balık tüketimi ile ilgili olarak birkaç çalışma yapıımış olup, Sarı ve ark (2000), Ceylan (2006), Güngör (2014) ve Terin (2019) bu çalışmaların Van ili geneli için yapıldığı, metropol ilçe düzeyinde hiçbir çalışmanın yapılmadığı belirlenmiştir. Bu nedenle konu ile ilgili yeni çalışmalara ihtiyaç olduğu düşünülmüştür. Bu doğrultuda araştırmanın amacı, Van ili İpekyolu ilçesinde hanelerin balık tüketim sıklığına etki eden sosyo demografik faktörleri belirlemektir.

\section{Materyal ve Metot}

Çalışmanın ana kitlesini Van ili ìpekyolu ilçesinde yaşayan hane halkı toplamı oluşturmaktadır. ipekyolu ilçesi, TBMM'de 11 Kasım 2012 tarihinde çıkan 6360 sayılı yasa ile Van merkez ilçenin ikiye bölünmesi ile birlikte ilçe vasfı kazanmıştır. İpekyolu ilçesi, nüfus olarak Van'ın en büyük ilçesi olup, ilin hizmet ve ticaret merkezini oluşturmaktadır (Anonim, 2018b). 2017 yılı adrese dayılı nüfus verilerine göre Van ili merkez nüfusunun \%51.69'u İpekyolu ilçesinde ikamet etmektedir (Anonim, 2018c).

İpekyolu ilçesi gerek nüfus yoğunluğu gerekse balık satış yerlerinin büyük bir çoğunluğuna sahip olması ayrıca yerel ve ulusal süper ve hiper marketlerin önemli bir bölümünü içinde bulundurması nedeniyle çalışmanın ipekyolu ilçesinde yürütülmesinin daha doğru olacağı ve elde edilen sonuçların Van ilini temsil edeceği düşünüldüğünden çalışma İpekyolu ilçesinde yürütülmüştür.

Van ili İpekyolu ilçesi nüfusu adrese dayılı nüfus kayıt sistemine göre 300796 kişi (Anonim 2018c) ve hane halkı ortalaması 5.2 kişiden oluşmaktadır (Anonim, 2018d). Bu verilere göre, Van İli İpekyolu ilçesinde toplam 57845 adet hane yaşamını sürdürmektedir. Ana kitleyi temsil eden örnek hacmi aşağıdaki oransal örnekleme yöntemi kullanılarak belirlenmiştir (Miran, 2002). Örnek 
hacminin belirlenmesinde $\% 90$ güven aralığı ve $\% 5$ hata payı dikkate alınarak hesaplanmıştır.

Çalışmada hanelerin balık tüketme olasılığı (p), ilde daha önce Ceylan (2006) tarafından yapılan çalışmada 0.7853 olarak belirlenmiştir. Bu nedenle çalışmada örnek hacmi hesaplanırken, hanelerin balık tüketim olasılığını gösteren $p$ değeri 0.7853 olarak alınmıştır.

$$
n=\frac{N p *(1-p)}{(N-1) \sigma_{p_{x}}^{2}+p(1-p)}
$$

Burada, $\mathrm{n}$; örnek hacmini, $\mathrm{p}$; incelenen olayın ana kitle içinde gerçekleşeme olasılığı (0.7853), (Ceylan, 2006) ve $\sigma_{p_{x}}^{2}$; Oranın varyansı (0.0304) göstermektedir. Hesaplama sonucunda örnek hacmi 182 olarak bulunmuştur. Araştırma verileri amaca uygun şekilde hazırlanan anket formları vasıtasıyla, tesadüfi olarak belirlenen hanelerden araştırmacı tarafından yüz yüze yapılan görüşmelerle toplanmıştır. Anketler 2017 Kasım, Aralık ve 2018 Ocak aylarında yapılmıştır.

$$
n=\frac{57845 * 0,7853 *(1-0,7853)}{57844 * 0,0304^{2}+0,7853 *(1-0,7853)}=182
$$

Çalışmada, hanelerin balık tüketim sıklığına etki eden sosyo-ekonomik ve demografik faktörler "Sıralı (Ordered) Probit Model" yöntemi kullanılarak tahmin edilmiştir. Yapılan literatür incelemelerinde tüketicilerin balık tüketim sıklığına etki eden faktörlerin belirlenmesinde birçok çalışmada sıralı probit modelin kullanıldığı tespit edilmiştir (Kumar ve ark., 2008; Puduri ve ark., 2010; Quagrainie ve ark., 2011; Perez-Ramirez ve ark., 2015; Higuchi ve ark., 2017; Lee ve Nam, 2019; Terin, 2019).

Ekonometrik analizlerde, bağımlı değişkenin ikiden fazla ve bu değişkenler arasında doğal bir sıralamanın olması durumunda ordered probit ve ordered logit modellerinin kullanılmasının uygun olacağı ifade edilmektedir (Abdel-Aty, 2001; Yavuz ve ark., 2018). Ordered probit modelinin, yukarıda belirtilen değişkenlere sahip veri setlerinin çözümünde kullanılan en yaygın ve en uygun modellerinden biri olması (Maddala, 1983) nedeniyle araştırmada bu model kullanılmıştır.

Ordered probit modeli, McFadden (1973)'ın fayda maksimizasyonu kuramına dayanmaktadır. Araştırmada fayda fonksiyonu, balık tüketim sıklığı sonucunda tüketicinin sağladığı faydayı göstermektedir. Fakat burada sağlanan faydanın düzeyi gözlenememektedir. Ordered probit modelinde gözlenebilir, aralıklı ve sıralı kategorilerin (y) ardında da sürekli, ancak gözlenemeyen gizli bir bağımlı değişken olduğu varsayılmaktadır. Gözlenemeyen, gizli bağımlı değişken $\left(y^{*}\right)$, açıklayıcı değişkenler vektörü ve hata terimi ile açıklanmaktadır. Hata teriminin normal dağılıma sahip olduğu varsayılır (Greene, 2012).

$$
y^{*}=x^{\prime} \beta+\varepsilon \quad \varepsilon \sim N[0,1]
$$

Burada, $y^{*} ; \quad$ gözlenemeyen bağımlı değişkeni, $x$; açıklayıcı değişkenler vektörünü, $\beta$; tahmin edilecek olan parametre vektörünü ve $\varepsilon$; hata terimini göstermektedir. Bağımlı değişken (y) ile gözlenemeyen bağımlı değişken $\left(y^{*}\right)$ arasındaki ilişki, tüketicilere göre ayrı değer alan ve regresyon katsayıları ( $\beta$ ) kullanılarak tahmin edilen eşik değerlerin $\left(\mu_{\mathrm{j}}\right)$ bir fonksiyonu olarak ele alınmaktadır.

Çalışmada hanelerin balık tüketimi için beş alternatiften birini seçtiklerinden, bağımlı değişken beş farklı değer alacak şekilde büyüklüklerine göre $(y=0,1,2,3,4)$ sınıflandırılmıştır. Buna göre; modelin bağımlı değişkeni (y) ile gözlenemeyen bağımlı değişkeni ( $y^{*}$ ) arasındaki ilişki aşağıdaki gibi oluşturulmuştur (Chen ve ark., 2002; Greene, 2012).

$\begin{array}{ll}\text { Eğer } y^{*} \leq 0, & y=0 \\ \text { Eğer } 0<y^{*} \leq \mu_{1}, & y=1 \\ \text { Eğer } \mu_{1}<y^{*} \leq \mu_{2}, & y=2 \\ \text { Eğer } \mu_{2}<y^{*} \leq \mu_{3} & y=3 \\ \text { Eğer } \mu_{3} \leq y^{*} & y=4\end{array}$

Araştırmada, modelde kullanılan bağımlı değişkenin sıralı kategorileri olan " $\mathrm{y}=0$ " değişkeni hiç balık tüketmeyen haneleri " $y=1$ " değişkeni ayda bir kez balık tüketen haneleri, " $y=2$ " değişkeni on beş günde bir balık tüketen haneleri, " $y=3$ " değişkeni haftada bir balık tüketen haneleri ve " $y=4$ " değişkeni ise haftada birden fazla balık tüketen haneleri göstermektedir. Sıralı probit modelinde tüketicilerin beş alternatiften birini seçme olasılığı aşağıdaki gibidir (Greene, 2012).

$$
\begin{aligned}
& \operatorname{Prob}(y=0 \mid x)=\Phi\left(-x^{\prime} \beta\right), \\
& \operatorname{Prob}(y=1 \mid x)=\Phi\left(\mu_{1}-x^{\prime} \beta\right)-\Phi\left(-x^{\prime} \beta\right), \\
& \operatorname{Prob}(y=2 \mid x)=\Phi\left(\mu_{2}-x^{\prime} \beta\right)-\Phi\left(\mu_{1}-x^{\prime} \beta\right), \\
& \operatorname{Prob}(y=3 \mid x)=\Phi\left(\mu_{3}-x^{\prime} \beta\right)-\Phi\left(\mu_{2}-x^{\prime} \beta\right), \\
& \operatorname{Prob}(y=4 \mid x)=1-\Phi\left(\mu_{3}-x^{\prime} \beta\right)
\end{aligned}
$$

Bütün bu olasılıkların pozitif olması için $\mu$ değerlerinin $0<\mu_{1}<\mu_{2}<\ldots<\mu_{\mathrm{j}-1} \Phi$ kümülatif normal dağılım fonksiyonunu göstermektedir. Modelin çözümü "logaritmik maksimum olabilirlik" yöntemiyle gerçekleştirilebilmektedir. Açıklayıcı değişkenlerin olasılıklar üzerindeki etkileri açıklayıcı değişkenlerin değerlerine bağlı olması nedeniyle, parametre $(\beta)$ tahminleri ile aynı değildir. Bu durum olasılıklar üzerindeki etkinin belirlenebilmesi için açıklayıcı değişkenlerin birim (marjinal) etkilerinin tahmin edilmesi gerekmektedir. Değişkenlerin birim etkileri, her bir olasılık için aşağıdaki gibi hesaplanmaktadır (Greene, 2012). 
$(\partial \operatorname{Prob}(y=0 \mid x)) / \partial \boldsymbol{x}=-\emptyset\left(\boldsymbol{x}^{\wedge^{\prime}} \beta\right) \beta$,

$(\partial \operatorname{Prob}(y=1 \mid \boldsymbol{x})) / \partial \boldsymbol{x}=\left[\emptyset\left(-\boldsymbol{x}^{\wedge^{\prime}} \beta\right)-\emptyset\left(\mu 1-\boldsymbol{x}^{\wedge^{\prime}} \beta\right)\right] \beta$,

$(\partial \operatorname{Prob}(y=2 \mid \boldsymbol{x})) / \partial \boldsymbol{x}=\left[\varnothing\left(\mu 1-\boldsymbol{x}^{\wedge^{\prime}} \beta\right)-\emptyset\left(\mu 2-\boldsymbol{x}^{\wedge^{\prime}} \beta\right)\right] \beta$,

$(\partial \operatorname{Prob}(y=3 \mid x)) / \partial \boldsymbol{x}=\left[\varnothing\left(\mu 2-\boldsymbol{x}^{\wedge^{\prime}} \beta\right)-\emptyset\left(\mu 3-\boldsymbol{x}^{\wedge^{\prime}} \beta\right)\right] \beta$,

\section{Bulgular ve Tartışma}

Modelde kullanılan değişkenlere ait tanımlayıcı istatistikler Çizelge $1^{\prime}$ de verilmiştir. Araştırmada hanelerin \%30,8'inin haftada bir, $\% 26,4$ 'ünün on beş günde bir, \%22,0'sinin ayda bir ve $\% 13,7^{\prime}$ sinin haftada birden fazla balık tükettikleri belirlenmiştir (Çizelge 1). Sırbistan'da yapılan çalışmada bireylerin \%52,24'ünün haftada bir (Djordjevic ve ark., 2015), Meksika'da yapılan çalışmada bireylerin \%24,24'ünün on beş günde bir (Perz-Ramirez ve ark., 2015), Ardahan ilinde yapılan çalışmada tüketicilerin \%26,16'sının haftada bir (Kılış ve ark., 2019), ABD'de yapılan çalışmada bireylerin \%24'ünün haftada bir (Hicks ve ark., 2008), Erzincan ilinde yapılan çalışmada tüketicilerin \%50'sinin on beş günde bir (Karakaya ve ark., 2020) ve Güney Kore'de yapılan çalışmada hanelerin \%7,3'ünün haftada bir ve daha fazla sıklıkta (Lee ve Nam, 2019) balık tükettikleri tespit edilmiştir.

Çizelge 1. Modelde kullanılan değişkenlere ait tanımlayıcı istatistikler

\begin{tabular}{lrr}
\hline Değişkenler & & Değerler \\
\hline Bağımlı değişken & & \\
\hline Hanelerin balık tüketim sıklığı & $Y=0$ & $\% 7,1$ \\
Hiç tüketmeyen & $Y=1$ & $\% 22,0$ \\
Ayda bir tüketen & $\mathrm{Y}=2$ & $\% 26,4$ \\
Ayda iki defa tüketen & $\mathrm{Y}=3$ & $\% 30,8$ \\
Haftada bir tüketen & $\mathrm{Y}=4$ & $\% 13,7$ \\
Haftada birden fazla tüketen & & Ortalama \\
\hline Sürekli açıklayıcı değişkenler & & $35,78(11,24)$ \\
\hline Yaş & $75,88(37,77)$ \\
Balık tüketim harcaması (TL/Ay) & $1,19(0,71)$ \\
Kişi başına düşen aylık balık tüketim miktarı (kg) & $4,93(1,89)$ \\
Hane halkı büyüklüğü & Değerler \\
\hline Ikili açıklayıcı değişkenler & $\% 18,1$ \\
\hline Hane reisinin kadın olması & $\% 90,6$ \\
Sosyal güvenceye sahip olmak & $\% 56,0$ \\
Hanede tüketilen balık miktarını yeterli bulma & $\% 69,8$ \\
Hane reisinin evli olması & $\% 75,8$ \\
Balığı balıkçıdan satın alıyor olmak & $\% 39,6$ \\
Hane halkı gelirinin asgari ücretin altında olması & $\% 73,6$ \\
Hane reisi eğitim düzeyinin lise ve üzerinde olması &
\end{tabular}

Hanelerin balık tüketim sıklığını etkileyen sosyo-ekonomik ve demografik özelliklere ait sıralı probit model sonuçları Çizelge 2'de verilmiştir. Model, en çok olabilirlik yöntemine göre bütünüyle istatistiksel olarak anlamlı bulunmuştur $(p<0.000)$. Modelin katsayıları, z oranı ve standart hata kullanılarak test edilmiştir. Modelde tahmin edilen eşik değerler, tüketicinin fayda fonksiyonu ile tüketim sıklığı arasındaki sayısal ilişkiyi ifade etmektedir (Akbay ve ark., 2007; Terin ve Çelik Ateş, 2016). Maddala (1983)'e göre, eşik değerler pozitif ve $\mu 1<\mu 2<\mu 3$ olmalıdır. Modelin eşik değerleri pozitif ve istatistiksel olarak \%1 düzeyinde anlamlı bulunmuştur. $\mathrm{Bu}$ durum hanelerin balık tüketim sıklığı kategorilerinin uygun şekilde belirlendiğini göstermektedir.

Model sonuçlarına göre; yaş ve hane reisinin bayan olmasının hanelerin balık tüketim sıklığını azalttığı, hanede tüketilen balığı yeterli olduğunu düşünme, hane reisinin evli olması, aylık ortalama balık tüketim harcaması, balığı balıkçıdan satın alma, hanelerin aylık ortalama gelirlerinin asgari ücretin altında olması, kişi başına düşen balık tüketim miktarı ve hane halkı büyüklüğü değişkenlerinin hanelerin balık tüketim sıklığını arttırdığı belirlenmiştir. Elde edilen sonuçların ekonomik teoriye ve beklentilere uygun olduğu söylenebilir. 
Çizelge 2. Sıralı (Ordered) probit model sonuçları $(n=182)$

\begin{tabular}{|c|c|c|c|c|}
\hline Değişkenler & Katsayı & z-istatistiği & p-değeri & VIF \\
\hline Sabit & $-1.244^{*}$ & $-1,830$ & 0,068 & \\
\hline Yaş & $-0.019^{*}$ & -1.810 & 0.070 & 2.043 \\
\hline Hane reisi kadın olması & $-0.601^{* * *}$ & -2.430 & 0.015 & 1.236 \\
\hline Sosyal güvenceye sahip & 0.320 & 0.960 & 0.336 & 1.321 \\
\hline Tük. Balığı yeterli bulma & $1.224^{* * *}$ & 5,960 & 0.000 & 1.382 \\
\hline Hane reisinin evli olması & $0.516^{*}$ & 1.800 & 0.072 & 2.367 \\
\hline Aylık balık harcaması & $0.020^{* * *}$ & 6.600 & 0.000 & 1.853 \\
\hline Balıkçıdan balık alma & $0.660^{* * *}$ & 3.040 & 0.002 & 1.205 \\
\hline Asgari ücreti altı & $0.346^{*}$ & 1.740 & 0.082 & 1.307 \\
\hline KBDBT & $0.587^{* * *}$ & 3.130 & 0.002 & 2.362 \\
\hline Hane halkı büyüklüğü & $0.168^{* * *}$ & 2.640 & 0.008 & 1.936 \\
\hline Lise ve üzeri eğitim & 0.231 & 1.060 & 0.290 & 1.265 \\
\hline \multicolumn{5}{|l|}{ Threshold parameters } \\
\hline$\overline{\mu(1)}$ & $2.060^{* * *}$ & 13.340 & 0.000 & \\
\hline$\mu(2)$ & $3.451^{* * *}$ & 25.670 & 0.000 & \\
\hline$\mu(3)$ & $5.090^{* * *}$ & 27.240 & 0.000 & \\
\hline \multicolumn{2}{|c|}{ Log. Olabilirlik Fonksiyonu $=-172.435$} & \multicolumn{3}{|c|}{ Kısıtlı Log. Olabil Fonksiyonu= -274.520} \\
\hline Khi kare (11 d.f.) = 204.170 & Önem se & $(0.000)$ & & \\
\hline
\end{tabular}

Maksimum olabilirlik yöntemi kullanılarak tahmin edilen sıralı probit modeline ait değişkenlerin katsayılarının doğrudan yorumlanması sakıncalıdır (Akbay ve ark., 2007). Açıklayıcı değişkenlerin olasılıklar üzerindeki etkilerinin, açıklayıcı değişkenlerin değerlerine bağlı olması nedeniyle, parametre $(\beta)$ tahminleri ile aynı değildir. Sıralı probit modelinde ek hesaplama yapmadan katsayıların nasıl yorumlanacağı açık değildir. Bu durum olasılıklar üzerindeki etkinin belirlenebilmesi için açıklayıcı değişkenlerin marjinal etkilerinin tahmin edilmesini gerektirir (Greene, 2012). Bu sebeplerden dolayı, sıralı probit model sonuçlarına ait katsayıların yorumlanması hataya sebep olabileceği için hanelerin balık tüketim sıklığına etki eden faktörlerin marjinal etkileri hesaplanmış ve yorumlar marjinal etkilere göre yapılmıştır (Çizelge 3 ).

Araştırmada, hane reisi yaşı ile balık tüketim sıklığı arasında negatif ve istatistiksel olarak \%10 düzeyinde anlamlı bir ilişki tespit edilmiştir. Buna sonuca göre, hane reisinin yaşının artması, hanelerin balık tüketim sıklığını azaltmaktadır. Hane reisinin yaşında meydana gelecek bir yıllık artış, hanelerin ayda bir balık tüketme olasılığını $(y=1) \% 0.47$ oranında arttırırken, haftada bir balık tüketme olasılığını $(y=3) \quad \% 0.6$ oranında azaltmaktadır. ABD (Kumar ve ark., 2008), Nijerya (Fregene ve Olanusi, 2012) ve İtalya'da (Samoggia ve Castellini, 2018) yapılan çalışmalarda yaş ile balık tüketim sıklığı arasında negatif bir ilişki olduğu tespit edilmiştir.

Araştırmada, hane reisinin bayan olması ile balık tüketim sıklığı arasında negatif ve istatistiksel olarak \%5 düzeyinde anlamlı bir ilişki tespit edilmiştir. Buna sonuca göre, hane reisinin kadın olması hanelerin balık tüketim sıklığını azaltmaktadır. Hane reisinin kadın olması hanelerin ayda bir balık tüketme olasılığını $(y=1) \quad \% 16.9$ oranında arttırırken, haftada bir $(\mathrm{y}=3)$ ve haftada birden fazla $(y=4)$ balık tüketme olasılığını sırası ile \%17.8 ve \%2.1 oranında azaltmaktadır. İtalya'da yapılan çalışmada kadınların erkeklere göre balık tüketim sıklığının daha düşük olduğu (Samoggia ve Castellini, 2018) ve ABD'de yapılan çalışmada ise kadınların erkeklere göre balık tüketim sıklığının daha fazla olduğu (Puduri ve ark., 2010) tespit edilmiştir.

Araştırmada, hanelerinde yeterli miktarda balık tüketildiğini düşünme ile balık tüketim sıklığı arasında pozitif ve istatistiksel olarak \%1 düzeyinde anlamlı bir ilişki tespit edilmiştir. Buna sonuca göre, hanelerinde yeterli miktarda balık tüketildiğini düşünmek, hanelerin balık tüketim sıklığını arttırmaktadır. Hanelerinde yeterli balık tüketildiğini düşünen hanelerin düşünmeyenlere göre, ayda bir balık tüketme $(y=1)$ ve on beş günde bir balık tüketme $(\mathrm{y}=2)$ olasılığını sırasıyla $\% 30.9$ ve $\% 9,8$ oranında azaltırken, haftada bir $(y=3)$ ve haftada birden fazla $(\mathrm{y}=4)$ balık tüketme olasılığını sırası ile \%35,3 ve \%6,3 oranında arttırmaktadır.

Araştırmada, hane reisinin evli olması ile balık tüketim sıklığı arasında pozitif ve istatistiksel olarak \%10 düzeyinde anlamlı bir ilişki tespit edilmiştir. Buna sonuca göre, hane reisinin evli olması hanelerin balık tüketim sıklığını arttırmaktadır. Hane reisinin evli olması hanelerin ayda bir $(\mathrm{y}=1)$ balık tüketme olasılığını $\% 13,6$ oranında azaltırken, haftada bir $(y=3)$ ve haftada birden fazla balık tüketme olasılığını sırasıyla \%15,8 
ve \%2,1 oranında arttırmaktadır. ABD'de yapılan çalışmada hane reisinin evli olması ayda bir kez balık tüketim olasılığını \%4.8 oranında azalttı̆̆ı, haftada iki veya daha fazla balık tüketim olasılığını \%3.8 oranında arttırdığı tespit edilmiştir (Kumar ve ark., 2008). Malezya (Ahmed ve ark., 2011), Nijerya (Fregene ve Olanusi, 2012) ve Güney Kore'de (Lee ve Nam, 2019) yapılan çalışmalarda da hane reisi evli olan haneler ile balık tüketim sıklığı arasında pozitif bir ilişki olduğu tespit edilmiştir.

Araştırmada, balık tüketim harcaması ile balık tüketim sıklığı arasında pozitif ve istatistiksel olarak \%1 düzeyinde anlamlı bir ilişki tespit edilmiştir. Buna sonuca göre, hanede balık tüketim harcamasının artması, hanelerin balık tüketim sıklığını arttırmaktadır. Balık tüketim harcamasında meydana gelecek 10 TL'lik artış, hanelerin ayda bir $(y=1)$ ve on beş günde bir $(y=2)$ balık tüketme olasılığını sırasıyla \%5 ve \%3 oranında azaltırken, haftada bir $(y=3)$ ve haftada birden fazla $(y=4)$ balık tüketme olasılığını sırasıyla \%6 ve \%1 oranında arttırmaktadır.

Araştırmada, balığı balıkçıdan almayı tercih etme ile balık tüketim sıklığı arasında pozitif ve istatistiksel olarak \%1 düzeyinde anlamlı bir ilişki tespit edilmiştir. Buna sonuca göre, balığı balıkçıdan almayı tercih eden hanelerin balık tüketim sıklığının balığı diğer satış yerlerinden alanlara göre daha fazla olduğu söylenebilir. Hanelerin balığı balıkçıdan almayı tercih etmesi, hanelerin ayda bir $(\mathrm{y}=1)$ balık tüketim olasılığını $\% 18,2$ oranında azaltırken, haftada bir $(y=3)$ ve haftada birden fazla $(\mathrm{y}=4)$ balık tüketme olasılığını sırasıyla \%19,6 ve \%2,4 oranında arttırmaktadır.

Araştırmada, aylık hane halkı geliri asgari ücretin (2200 TL) altında olan haneler ile balık tüketim sıklığı arasında pozitif ve istatistiksel olarak \%10 düzeyinde anlamlı bir ilişki tespit edilmiştir. ilk bakışta ekonomik teoriye ters bir sonuç gibi görünse de Van ili İpekyolu ilçesinde hanelerin büyük çoğunluğu inci kefali tüketmektedir. Ince kefali balığının fiyatının diğer balıklara göre oldukça düşük olması geliri düşük olan hanelerin bu balığı daha fazla satın almalarına neden olmaktadır. Haneler ihtiyaç duyduğu protein ihtiyacını diğer protein kaynaklarına göre ucuz olan inci kefali balığını daha fazla tüketerek protein açı̆ı̆nı bu şekilde telafi etmektedir. Buna sonuca göre, aylık hane halkı geliri asgari ücretin (2200 TL) altında olması balık tüketim sıklığını arttırmaktadır. Aylık hane halkı geliri asgari ücretin (2200 TL) altında olması hanelerin ayda bir balık tüketme $(y=1)$ olasılığını \%8,1 oranında azaltırken, haftada bir $(y=3)$ ve haftada birden fazla $(y=4)$ balık tüketme olasılığını sırası ile $\% 11,0$ ve $\% 1,9$ oranında arttırmaktadır.

Araştırmada, kişi başına düşen aylık balık tüketim miktarı ile balık tüketim sıklığı arasında pozitif ve istatistiksel olarak \%1 düzeyinde anlamlı bir ilişki tespit edilmiştir. Buna sonuca göre, kişi başına düşen aylık balık tüketim miktarının artması, hanelerin balık tüketim sıklığını arttırmaktadır. Kişi başına düşen aylık balık tüketim miktarında meydana gelecek bir birimlik artış, hanelerin ayda bir $(y=1)$ ve on beş günde bir $(y=2)$ balık tüketme olasılığını sırasıyla $\% 14,2$ ve $\% 7,2$ oranında azaltırken, haftada bir $(\mathrm{y}=3)$ ve haftada birden fazla $(\mathrm{y}=4)$ balık tüketme olasılığını sırasıyla $\% 18,7$ ve \%2,9 oranında arttırmaktadır.

Araştırmada, hane halkı büyüklüğü ile balık tüketim sıklığı arasında pozitif ve istatistiksel olarak \%1 düzeyinde anlamlı bir ilişki tespit edilmiştir. Buna sonuca göre, hane halkı büyüklüğü arttıkça, hanelerin balık tüketim sıklığını arttırmaktadır. Hane halkı büyüklüğünde meydana gelecek bir kişilik artış, hanelerin ayda bir $(\mathrm{y}=1)$ ve on beş günde bir ( $\mathrm{y}=2$ ) balık tüketme olasılığını sırasıyla $\% 4$ ve $\% 2,1$ oranında azaltırken, haftada bir $(y=3)$ ve haftada birden fazla $(\mathrm{y}=4)$ balık tüketme olasılığını sırasıyla \%5,3 ve \%0,8 oranında arttırmaktadır. Puduri ve ark. (2010) tarafından yapılan çalışmada da hane halkı büyüklüğünün balık tüketim sıklığını arttırdığı belirlenmiştir.

Çizelge 3. Sıralı Probit modele ait birim etkiler

\begin{tabular}{|c|c|c|c|c|c|}
\hline Değişkenler & $Y(0)$ & $Y(1)$ & $Y(2)$ & $Y(3)$ & $Y(4)$ \\
\hline Yaş & 0.000 & $0.004^{*}$ & 0.002 & $-0.006^{*}$ & -0.001 \\
\hline Hane reisi kadın olması & 0.005 & $0.169^{* *}$ & 0.025 & $-0.178^{* * *}$ & $-0.021^{* * *}$ \\
\hline Sosyal güvenceye sahip & -0.002 & -0.086 & -0.022 & 0.098 & 0.012 \\
\hline Tük. Balığı yeterli bulma & $-0.009^{* *}$ & $-0.309^{* * *}$ & $-0.098^{* *}$ & $0.353^{* * *}$ & $0.063^{* * *}$ \\
\hline Hane reisinin evli olması & -0.003 & $-0.136^{*}$ & -0.041 & $0.158^{*}$ & $0.021^{*}$ \\
\hline Aylık balık harcaması & $-0.0007^{* * *}$ & $-0.005^{* * *}$ & $-0.003^{* *}$ & $0.006^{* * *}$ & $0.001^{* * *}$ \\
\hline Balıkçıdan balık alma & -0.005 & $-0.182^{* * *}$ & -0.033 & $0.196^{* * *}$ & $0.024^{* *}$ \\
\hline Asgari ücreti altı & -0.001 & $-0.081^{*}$ & -0.047 & $0.110^{*}$ & 0.019 \\
\hline KBDBT & $-0.002^{* *}$ & $-0.142^{* * *}$ & $-0.072^{* *}$ & $0.187^{* * *}$ & $0.029^{* *}$ \\
\hline Hane halkı büyüklüğü & $-0.0006^{*}$ & $-0.0404^{* *}$ & $-0.021^{*}$ & $0.053^{* *}$ & $0.008^{* *}$ \\
\hline Lise ve üzeri eğitim & -0.001 & -0.0586 & -0.023 & 0.073 & 0.0103 \\
\hline
\end{tabular}

*:0.1, **:0.05 ve ***:0,01 önem 


\section{Sonuç ve Öneriler}

Bu çalışmada, Van ili ípekyolu ilçesinde hanelerin balık tüketim sıklığına etki eden sosyoekonomik ve demografik faktörler sıralı probit model kullanılarak analiz edilmiştir. Çalışma sonuçları, hanelerin sahip olduğu sosyo-ekonomik ve demografik özelliklerin hanelerin balık tüketim sıklıklarını önemli oranda etkilediğini ortaya koymuştur.

Araştırma sonuçlara göre; yaş ve hane reisinin bayan olmasının hanelerin balık tüketim sıklığını azalttığı, hanede tüketilen balığı yeterli görme, hane reisinin evli olması, aylık ortalama balık tüketim harcamasının artması ve balığı balıkçıdan satın alma değişkenlerinin hanelerin balık tüketim sıklığını arttırdığı belirlenmiştir. Modelden elde edilen sonuçların ekonomik teori ve beklentilere uygun olduğu söylenebilir.

Çalışmada hane reisinin kadın olmasının balık tüketim sıklığını düşürdüğü belirlenmiştir ki, özellikle çocukların gelişiminde balık tüketiminin çok önemli olması nedeniyle annelerin bu konuda daha hassas olması ve dengeli beslenme konusunda eğitim çalışmaları yapılarak, balık tüketim sıklığının arttırılması sağlanabilir. Çalışmada ilçedeki balık satış yerlerinin yeterli fakat balık restoranlarının yetersiz olduğu belirlenmiştir. Balığın kokusu ve pişirmesinin zahmetli olması düşünüldüğünde evde balık tüketmeyen haneler için yeterli sayıda ve kalitede balık restoranlarının olması tüketimi arttıracaktır. Bu nedenle özellikle yerel yönetimlerin bu konularda öncülük etmesi ve sosyal tesislerinde balık restoranlarına veya balık menülerine yer vermesi tüketime olumlu katkı sağlayacaktır.

Hanelerin aylık balık harcaması arttıkça balık tüketim sıklığının da arttığı tespit edilmiştir. Harcamanın gelir ile doğru orantılı olduğu düşünüldüğünde hanelerin gelirlerini arttırıcı veya balık fiyatlarının düşürülmesine yönelik politikaların (toptan ve perakende satışlarda KDV indirimi vb.) uygulanması veya teşvik edilmesi hanelerin balık tüketim sıklığını olumlu yönde etkileyeceği söylenebilir.

Çalışmada, balığı sabit balıkçıdan alan hanelerin balık tüketim sıklığının daha fazla olduğu belirlenmiştir. Balığı aynı yerden almak, alıcı ve satıcı arasında bir güven oluşturduğundan bu durum tüketicilerin daha sık balık tüketmesine olumlu katkı sağlamaktadır. Bu nedenle balık satıcılarının tüketici davranışlarına ve isteklerine uygun davranışlar göstermesi hanelerin balık tüketim sıklığını arttırabilecektir.

Hane reisinin evli olması balık tüketim sıklığını arttıran önemli bir faktördür. Çünkü balığın tüketime hazır hale getirilmesi zahmetli bir süreci beraberinde getirmektedir. $\mathrm{Bu}$ nedenle hane reisinin evli olması tüketim sıklığını arttırmaktadır. Ancak ilçede balık restoranlarının sayısının arttırılması ve balık satış yerlerinde pişirme hizmetinin de verilmesi ile hane reisi evli olmayan hanelerinde balık tüketim sıklığı arttırılabilir.

Araştırmada, hane halkı gelirinin asgari ücretin (2200 TL) altında kalan hanelerin balık tüketim sıklığının daha fazla olduğu söylenebilir. Bu durum iki şekilde açıklanabilir, birincisi inci kefali fiyatlarının diğer balıklara göre daha ucuz ve bölge halkı tarafından tüketiminin bir kültür haline gelmiş olması nedeniyle sık tüketilmesi, ikincisi aylık ortalama gelir düzeyi asgari ücretin üstünde olan hanelerin balıktan daha çok kırmızı eti tercih ediyor olmaları veya gelir düzeyi asgari ücretin üzerinde olan hanelerin fiyatı yüksek balıkları tercih etmesi nedeniyle daha az sıklıkta balık tüketiyor olmasıdır.

Van Gölü sayesinde, bölgede balık tüketim alışkanlığının bir kültür haline geldiği ve hanelerin önemli bir kısmının balık tükettiği ipekyolu ilçesinde, özellikle balıkların muhafaza, taşıma, saklama ve işleme gibi koşullarının geliştirilmesiyle birlikte tüketimin mevcut durumdan daha iyi bir noktaya getirilebilmesi sağlanabilecektir.

\&: Bu çalışma Seda Terin'in "Van İli İpekyolu İlçesinde Balık Tüketim Tercihleri Üzerine Bir Araştırma" isimli Yüksek Lisans Tezinden türetilmiştir.

Çıkar Çatışması Beyanı: Makale yazarları aralarında herhangi bir çıkar çatışması olmadığını beyan ederler.

Araştırmacıların Katkı Oranı Beyan Özeti: Yazarlar makaleye eşit oranda katkı sağlamış olduklarını beyan ederler.

\section{Kaynaklar}

Abdikoğlu, D.i. Azabağaoğlu, M.Ö. ve Unakıtan, G. 2020. An Econometric Analysis of Factors Affecting Fish Consumption: The Case of Tekirdag, Turkey. KSU J. Agric Nat 23,446452.

Abdel-Aty, M.A. 2001. Using ordered probit modeling to study the effect of ATIS on transit ridership. Transportation Research Part C: Emerging Technologies, 9(4): 265277.

Ahmed, A.F. Mohamed, Z. ve Ismail, M.M. 2011. Determinants of Fresh Fish Purchasing Behavior Among Malaysian Consumers. Current Research Journal of Social Sciences, 3, 126-131.

Akbay, C. Tiryaki, G.Y. ve Gül, A. 2007. Consumer characteristics influencing fast food 
consumption in Turkey. Food Control, 18, 904-913.

Anonim, 2018a. Van Tarım ve Ormancılık il Müdürlüğü Kayıtları.

Anonim, 2018b. TC. ipekyolu Kaymakamlı̆̆, http://ipekyolukaymakamligi.gov.tr/ipekyolu Erişim tarihi: 16.11.2018.

Anonim, 2018c. Türkiye istatistik Kurumu, https://biruni.tuik.gov.tr/medas/?kn=95\&loca le=tr Erişim tarihi: 10.10.2018.

Anonim, 2018d. Türkiye istatistik Kurumu, http://www.tuik.gov.tr/PreHaberBultenleri.d o?id=27597 Erişim tarihi: 10.10.2018.

Anonim, 2020. T.C. Tarım ve Orman Bakanlığı Su Ürünleri İstatistikleri.

Aydın, M. ve Karadurmuş, U. 2013. Trabzon ve Giresun Bölgelerindeki Su Ürünleri Tüketim Alışkanlıkları. Karadeniz Fen Bilimleri Dergisi, 3(9): 57-71.

Beyazbayrak, Z. 2014. Kahramanmaraş ili merkez ilçede balık tüketim alışkanlıkları. (Yüksek Lisans Tezi), Kahramanmaraş Sütçü İmam Üniversitesi Fen Bilimleri Enstitüsü, Kahramanmaraş

Ceylan, M. 2006. Van ili kentsel ve kırsal alanda et ve ürünleri tüketim yapısı ve tüketicilerin satın alma eğilimleri. (Yüksek Lisans tezi), Yüzüncü Yıl Üniversitesi Fen Bilimleri Enstitüsü, Van.

Chen, K. Ali, M. Veeman, M. Unterschultz, J. ve Le, T. 2002. Relative importance rankings for pork attributes by Asian-origin consumers in California: Applying an ordered probit model to a choice-based sample. Journal of Agricultural and Applied Economics, 34, 6779.

Djordjevic, V. Sarcevic, D. ve Petronijevic, R. 2015. The attitudes and habits of Serbian schoolchildren to consumption of fish. Procedia Food Science, 5, 73-76.

Elbek, A.G. İsgören Emiroglu, D. ve Saygı, H. 1997. Balık tüketimi ve tüketimine yönelik sörvey. Akdeniz Balıkçılık Kongresi, İzmir.

FAO, 2018. The State of World Fisheries and Aquaculture 2018- Meeting the sustainable development goals. ISBN 978-92-5-130562-1, Roma.

Fregene T.B. ve Olasnusi, A. 2012. Consumer Preference and Consumption Pattern of Marine Fish Species in Ibadan Metropolis, Oyo State, Nigeria. Journal of Agricultural Science and Technology, B2, 835-840.

Gilbert, L.C. 2000. The functional food trend: What's next and what Americans think about eggs. Journal of the American College of Nutrition, 19 (5): 507-512.

Greene W.H. 2012. Econometric Analysis. Seventh Edition. Pearson Prentice-Hall, Upper Saddle
River, New Jersey, 07458. ISBN 10:0-13139538-6

Gül Yavuz, G. Yasan Ataseven, Z. Gül, U. ve Gülaç, Z.N. 2015. Su Ürünleri Tüketiminde Tüketici Tercihlerini Etkileyen Faktörler: Ankara ili Örneği. Yunus Araştırma Bülteni, 1, 73-82

Güngör, E.S. 2014. Erzurum ve Van Illerindeki Balık Tüketimi ve Tüketici Tercihleri Üzerine Bir Araştırma. (Yüksek Lisans Tezi), Atatürk Üniversitesi Fen Bilimleri Enstitüsü, Erzurum.

Hatırlı, S.A. Demircan, V. ve Aktaş, A. 2004. Isparta illinde Ailelerin Balık Tüketiminin Analizi. Süleyman Demirel Üniversitesi Iktisadi ve Idari Bilimler Fakültesi Dergisi, 9(1): 245-256.

Hicks, D. Pivarnik, L. ve Mc Dermott, R. 2008. Consumer perceptions about seafood-an Internet survey. Journal of Food Service, 19, 213-226.

Higuchi, A. Davalos, J. ve Hernani-Merino, M. 2017. Theory of planned behavior applied to fish consumption in modern Metropolitan Lima. Food Science and Technology, 37(2): 202-208.

Karakaya, E., Kırıcı, M. 2016. Bingöl ili il merkezinde balık eti tüketim alışkanlıklarının belirlenmesi. International Journal of Social and Economic Sciences 6 (1): 74-85.

Karakaya E, Çelik Ş, Taysi M. R 2018. CHAID Algoritması ile Balık Eti Tüketimini Etkileyen Faktörlerin Incelenmesi. Gaziosmanpaşa Üniversitesi Ziraat Fakültesi Dergisi, 35(2), 85 - 93.

Karakaya, E. Sökmen, T.Ö. ve Kırıcı, M. 2020. Erzincan İli Balık Tüketim Alışkanlıklarının Belirlenmesi. Menba Kastamonu Üniv. Su Ürünleri Fakültesi Dergisi, 6(1):18-29.

Karakaya, E, Kırıcı, M, Çam, O. 2018. Siirt ili kent merkezinde balıketi tüketim yapısı ve tüketicilerin satın alma eğilimlerinin belirlenmesi. Akademik Ziraat Dergisi, 7 (2):227-236.

Kılıç, E. Soylu, M. ve Uzmanoğlu, M.S. 2019. Determination of Consumption Habits of Aquatic Products in Ardahan Province. Turkish Journal of Agriculture - Food Science and Technology, 7(7): 1028-1039.

Kornitzer, M. 2001. Fish and health among adults. In Descheemaeker K, Provoost C. Impact of food on health-Recent developments, Antwerpen: Garant, 53-65.

Kumar, G. Quagrainie, K. ve Engle, C. 2008. Factors that influence frequency of purchase of catfish by U.S. households in selected cities. Aquaculture Economics and Management, 12, 252-267.

Lee, M.K. ve Nam, J. 2019. The determinants of live fish consumption frequency in South Korea. Food Research International, 120, 382-388. 
Leek, S. Maddock, S. ve Foxall, G. 2000. Situational determinants of fish consumption. British Food Journal, 102 (1): 18-39.

Maddala, G.S. 1983. Limited-dependent and qualitative variables in econometrics. New York: Cambridge University Press.

Mangen, M.J. ve Burrell, A.M. 2001. Decomposing preference shifts for meat and fish in the Netherlands. Journal of Agricultural Economics, 52(2): 16-28.

McFadden, D. 1973. Conditional logit analysis of qualitative choice behavior. In P. Zarembka (Ed.), Frontiers in econometrics New York: Academic Press.

Miran, B. 2002. Temel İstatistik. Ege Üniversitesi, Bornova, İzmir.

Myrland, O. Trondsen, T. Johnston, R.S. ve Lund, E. 2000. Determinants of seafood consumption in Norway: lifestyle, revealed preference and barriers to consumption. Food Quality and Preference, 11(3): 169-188.

Pérez-Ramírez, M. Almendarez-Hernández, M.A. Avilés-Polanco, G. ve Beltrán-Morales, L.F. 2015. Consumer acceptance of eco-labeled fish: A Mexican case study. Sustainability, 7, 4625-4642.

Puduri, V.S. Govindasamy, R. Myers, J.J. ve O'Dierno, L.J. 2010. Demand for live aquatic products in the Mid-Atlantic States: An ordered probit analysis towards consumers' preferences. Aquaculture Economics and Management, 14, 30-42

Quagrainie, K. Xing, A. Hughes, K.G. 2011. Factors influencing the purchase of live seafood in the North Central region of the United States. Marine Resource Economics, 26, 59-74.

Rickertsen, K. 1996. Structural change and the demad for meat and fish in Norway. European Review of Agricultural Economics, 23(3): 316330.

Samoggia, A. ve Castellini, A. 2018. Health-Orientation and Socio-Demographic Characteristics as Determinants of Fish Consumption. Journal of International Food \& Agribusiness Marketing, 30, 211-226.

Sarı, M. Demirulus. H. ve Söğüt. B. 2000. Van ilinde Öğrencilerin Balık Eti Tüketim Alışkanlığının Belirlenmesi Üzerine Bir Araştırma. Doğu Anadolu Bölgesi Su Ürünleri Sempozyumu, 28-30 Haziran, Erzurum.
Saygı, H. Bayhan, B. ve Hekimoğlu, M.A. 2015. Türkiye'nin İzmir ve Ankara illerinde su ürünleri tüketimi. Türk Tarım-Gıda Bilim ve Teknolojisi Dergisi, 3(5): 248-254.

Şen, A. 2011. Konya ve Mersin il Merkezlerinde Yaşayan Bireylerin Balık Tüketim Konusundaki Alışkanlık ve Bilgi Düzeylerinin Karşılaştırılması. (YL.Tezi), Selçuk Üniversitesi Sosyal Bilimleri Enstitüsü, Konya.

Tatar, O. 1995. Nutritional properties of fish and healthy respect. E.U. Journal of Fisheries \& Aquatic Sciences, 12, 169-170.

Terin, M. ve Çelik Ateş, H. 2016. Tarımda Örgütlenmeye Etki Eden Faktörlerin Belirlenmesi Üzerine Bir Çalışma: Van ili Örneği. Türk Tarım ve Doğa Bilimleri Dergisi 3, 38-44.

Terin, M. 2019. Household characterıstıcs influencıng fish consumption in Van Province, Turkey. Ital. J. Food Sci., 31, 416-426.

Terin, M. Hamamcı, G. Gül, T. ve Terin, S. 2016. Determination of households fish consumption structure and purchase behaviors in urban areas of Van. Ege Journal of Fisheries and Aquatic Sciences, 33, 241-249

Trondsen, T. Braaten, T. Lund, E. ve Eggen, A.E. 2004. Health and seafood consumption patterns among women 45-69 years. A Norwegian Fish Consumption Study 1996. Food Quality and Preference, 15(2):117-128.

Turan, H. Kaya, Y. ve Sönmez, G. 2006. Balık Etinin Değeri ve İnsan Sağlığındaki Yeri. E.U. Journal of Fisheries \& Aquatic Sciences, 23, 505-508.

TÜiK, 2019. TÜiK Su Ürünleri 2018 istatistikleri.

Uzundumlu, A.S. Topcu, Y. ve Baran, D. 2013. Tüketicilerin balıketi tüketimini etkileyen faktörlerin belirlenmesi: Erzurum ili örneği. İç Anadolu Bölgesi 1. Tarım ve Gıda Kongresi, 24 Ekim 2013, Niğde.

Verbeke, W. ve Vackier, I. 2005. Individual determinants of fish consumption: application of the theory of planned behaviour. Appetite, 44(1): 67-82.

Yavuz, F. Shiwan, M.S. Terin, M.Akay, B. Güler, I.O. ve Ağsu,K. 2018. Gelir Getirici Faaliyetlere Karar Vermede Kırsal Kadının Rolü: Kuzeydoğu Anadolu TRA1 Bölgesi Örneği. Uluslararası iktisadi ve idari incelemeler Dergisi, 18. EYi Özel Sayısı: 1-10. 